\title{
BIO-RATIONAL MANAGEMENT OF ARMYWORM (MYTHIMNA SEPARATA) (LEPIDOPTERA: NOCTUIDAE) IN CHITWAN CONDITION OF NEPAL
}

\author{
S. Sharma ${ }^{1 *}$, G.S. Bhandari², S. Neupane ${ }^{2}$, A. Pathak ${ }^{2}$ and S. Tiwari ${ }^{3,4}$ \\ ${ }^{1}$ Nepal Agriculture Research Council, Entomology Division, Khumaltar, Lalitpur, Nepal \\ ${ }^{2}$ Nepal Agriculture Research Council, Rampur, Chitwan, Nepal \\ ${ }^{3}$ Agriculture and Forestry University, Department of Entomology, Rampur Chitwan \\ ${ }^{4}$ Bio-protection Research Centre, Lincoln University, New Zealand. \\ *newento2014@gmail.com
}

\begin{abstract}
The armyworm, Mythimna separata Walker is the potential insect pest of maize, causes a severe damage on the vegetative and reproductive stages of that plant. Insecticides are the common practices to manage the broad categories of the pest in a maize field. Further, these practices have been linked to farmers health, biodiversity loss and declining of predatory arthropods. However, pest management by adopting a tool of integrated pest management is one potential option to reduce the pesticide in maize fields. Field experiments were conducted in winter maize with the aim of evaluating the potential bio-rational pesticides to manage the armyworm. The studies were conducted for two consecutive years in 2015/16 and 2016/17 at Rampur, Chitwan. Treatments were: Metarrhizium anisopliae (0.2ml/lit water), Nuclear Polyhedrosis Virus (NPV) ( $2.5 \mathrm{gm} /$ lit water), Spinosad 45\% SC (0.25 ml/liter of water), Multineem (Azadriachta indica) (2 .0 ml/ liter water), Furadan 3G (3-4g/ Whorl application), Lara (Chloropyriphos $50 \mathrm{EC}+$ Cypermethrin 5 EC) (1.0 ml/liter of water), Magik (Imidacloprid $17.8 \%(0.5 \mathrm{ml} /$ liter of water) and Control. The experiments were completely randomized block design with three replicates. Spinosad treated plots demonstrated the lowest damage $(0.884 \%)$ followed by Magik $(1.27 \%)$ which was significantly lower $(\mathrm{P}<0.05)$ than other treatments in 2015/2016. However, in $2016 / 2017$, Spinosad treated plot also showed the significantly lowest damage $(1.67 \%)$ followed by Lara plots $(2.67 \%)$, both of these were significantly different $(\mathrm{P}<0.05)$ to Metarhizium and control plots, but similar to the other treatments, but not significantly so. Maximum yield was recorded in spinosad treated plots $(9.8 \mathrm{t} / \mathrm{ha}$ and $9.12 \mathrm{t} / \mathrm{ha})$ followed by Lara treated plots $(9.17 \mathrm{t} / \mathrm{ha}$ and $8.69 \mathrm{t} /$ ha) and were lowest in control plots ( $4.55 \mathrm{t} / \mathrm{ha}$ and $7.18 \mathrm{t} / \mathrm{ha}$ ) for both years. Hence, Spinosad (soil actinomycete bacterium, Saccharopolyspora spinose) has the potentiality to maximize the maize yield and also potentially to the reduce the pesticide consumption and incurred cost caused by the pesticide use. Such a safe and eco-friendly insecticide has the potential to replace the synthetic pesticide and provide the benign environment to the natural predators and service providing units of multiple ecosystem services in maize agro-ecosystem.
\end{abstract}

\section{INTRODUCTION}

A number of insect pests have been recorded in maize fields and production loss has been recorded up to $75 \%$ (Songa et al., 2002). Mythimna separata (Noctuidae: Lepidoptera) is an important polyphagous insect with its erratic occurrence in cereal crops (Ali, Rashid, Huang, \& Lei, 2016). These pest damages the crop by defoliating the foliage part of plants including tender stems, maize tassel, cobs. etc and There has been up to $44 \%$ in maize fields (Juan, Yuying, \& Jie, 2013). $M$. separata is also the noxious pest of several other plants such as rice, sorghum, sugarcane, oats, 
wheat etc.(Jiang, Zhang, Cheng, \& Luo, 2014). Fourth and fifth instars larva are the major damaging stages and defoliate the maize crop (Neupane et al., 1992). These larvae not only feed the leaves but also damage the inflorescences, ears, growth points and finally the grains and finally caused a heavy decline in yield (GC and Keller, 2013).

It has been recorded from 27 countries, territories and islands ranging from the humid tropics to the temperate regions (Sharma \& Davies, 1983). Injury to maize is caused by a single generation of M. separata larvae, usually during the time of grain filling (January-March) (Hill and Atkins, 2012). In Nepal, their damages have been recorded in many parts of the country such as Palpa, Argakhanchi and Gulmi districts (Rana \& Plumb, 1973; Gyawali, 1974), Kavre and Sindhupalchowk districts (Rana, 1975) and Nuwakot and Rasuwa districts (Joshi, 1978). Anonymous (1976) reported M. separata also epidemic to maize crops in Jumla, Humla, Bajhang, Lamjung, Rasuwa, Nuwakot, Syangja, Kaski, Nawalparasi, Chitwan, Makwanpur, Bara, Parsa, Sarlahi, Mahottari, Dhanusa, Kathmandu, Bhaktapur and Lalitpur districts. In Nepal, winter maize is more susceptible to this pest (Shivakoti \& K.C., 1981). In hilly districts of Nepal, pesticide use is not a norm and has been using the very negligible amount of pesticides (Tiwari et al., unpublished data). But the case is just opposite in Chitwan district including other plain areas near to the big market where maize cobs have been sold for fresh consumption. Growers normally use the broad spectrum pesticide to control the broad categories of insect pest. These practices sometimes called unhealthy agricultural practices. These practices are extremely toxic for insect natural enemies (Cloyd \& Bethke, 2011), bumble bees (Whitehorn, O'Connor, Wackers, \& Goulson, 2012) and many other insect pollinators (Godfray et al., 2014) including birds and many fish species (Gibbons et al., 2015). In another side, some other indirect effects of pesticides have been realized in our environments such as pollution of waterways and marine environments, biodiversity loss, loss of certain natural non-traded ecosystem services (Karuppuchamy \& Venugopal, 2016; Tiwari, Dickinson, Saville, \& Wratten, 2018), extinction of many plants and animal species and finally disturbance to agricultural ecosystem services (Geiger et al., 2010; McLaughlin \& Mineau, 1995; Robinson \& Sutherland, 2002).

Hence, there is increasing pressure from the consumers, media and governments to reduce the pesticide in our agro-ecosystem but no alternatives are currently available to manage the $M$. separata pest in that country. It is, therefore, necessary to develop a cost-effective, non-chemical and sustainable method of pest management. Hence, integrated pest management was born in the late 1950s to minimize the crisis of overuse of harmful synthetic chemical pesticides (Brunner, 2014) and on which has been carried the core principles of ecology (Brunner, 2014). Total replacement of current pesticides from the market and total organic maize production are not possible. Hence, adopting the principle of integrated pest management could be one option to immediate lower down the current use of pesticides. Judicious selection of pesticide has been realized, which were evaluated and tested in a maize field. The current market available pesticides are not equally effective for the management of M. separata. Farmers have been troubled from the agro-vets and they are forced to use chemical pesticides. To balance both situations, the study aimed to select the suitable and ecofriendly pesticides applicable to the farmers which fully considered the broad aspects of integrated pest management.

\section{MATERIALS AND METHODS}

The field experiments were conducted at the National Maize Research Program, Bharatpur Chitwan (approximately 2740'59.99" N 84²5'59.99" E), Nepal from October to April of 2015/2016 
and 2016/2017. Eight potentially safe pesticides were bought from Chitwan market and tested their efficiency in field conditions to manage the armyworm. Maize variety cv. Rampur Hybrid was planted in a plot of $5 \mathrm{~m}$ by $4 \mathrm{~m}$ in a crop geometry of $60 \mathrm{~cm}$ x $20 \mathrm{~cm}$. The experiment design was a completely randomized block design with three replicates. The three-meter distance was maintained between the treatment plots and the control plot was $5 \mathrm{~m}$ apart from the treatment plot. Eight treatments were compared with a control plot and altogether there were nine treatments including control. They were: Metarrhizium anisopliae - $0.2 \mathrm{ml} /$ lit water, Nuclear Polyhedrosis virus (NPV)- $2.5 \mathrm{gm} /$ lit water, Spinosad 45\% SC @ 0.25ml/liter of water, Multi-neem (Commercial product of Azadirachta indica) @ $2.0 \mathrm{ml} /$ liter water, Whorl application of Furadan 3G@3-4 G/ Whorl, Lara (Chloropyriphos 50 EC+Cypermethrin 5 EC) @ 1.0 ml/liter of water, Magik (Imidacloprid 17.8\%) @ 0.5ml/liter of water and Control. The treatments were applied (first spray) at the knee height stage of maize crop (1 month after sowing). The second spray was made on 15-days after the first spray and the third spray was on 15-days after the second spray. First data was recorded a day before first spray, second, third and fourth data were collected on 1 wk after each spray. The same research designs, field layout, cultivation practices, pesticide spray and data collection protocols were followed for both years. Total numbers of armyworm damaged plants from each plot were individually counted before the spray and after the spray, and finally, total yield from each plot in both years were weighted.

The mean damage percentage in each treatment plot was statistically analyzed by two-way analysis of variance (ANOVA) using the Genstat statistical package (GenStat 16, VSN International, Hemel Hempstead, Hertfordshire HP1 1ES, United Kingdom). Mean damage percentage in each treatment approximately followed a normal distribution by the Central Limit Theorem ((see Wood and Saville (2013) for a fuller discussion)). Mean between the treatments were separated by the protected least significance difference (LSD) at $\mathrm{P}<0.05$ (Saville, 2015).

\section{RESULTS AND DISCUSSION}

\section{Damage percentage}

a. Damage record by M. separata in 2015/2016

Armyworm damages were significantly different $(\mathrm{P}<0.05)$ before and after the spray over the sampling periods (Table 1). Significant different on damage percent in maize field before spray indicated that there was already damage started in the maize field but that damage was not same in the field. Variation in damage in the field might be the abnormal distribution pattern of armyworm in the field (Ali, Luttrell, \& Pitre, 1990; Nagoshi \& Meagher, 2004). In the fields, where their population are high, resources are high (resource concentration theory) (Russell, 1989), plant starts to show the damage threshold, which could potentially damage some plots by more intensively and more obvious than the other plots. However, the damage on spinosad treated plots in each spray was also significantly lower than the control plot $(\mathrm{P}<0.05)$ over the sampling periods. After second and third spray of the treatments, the damage on the plants were lowest in spinosad $(0.88 \%$ and $0.88 \%$ respectively) followed by Magik (1.28 \% and $1.275 \%$ ), both were not significantly different from each other but were significantly different from the control plot for both times $(3.57 \%$ and $4.99 \%)$ (Table 1). 
Table 1: Response of different pesticides on armyworm (Mythimna separata) damage in a maize field in 2015/16 in Chitwan, Nepal.

\begin{tabular}{lllll}
\hline \multirow{2}{*}{ Treatments } & \multicolumn{4}{l}{ Damage (\%) } \\
\cline { 2 - 5 } & Before spray & After 1st spray & After 2nd spray & After 3rd spray \\
\hline Metarrhizium anisopliae & $1.51 \mathrm{~d}$ & $1.41 \mathrm{abc}$ & $2.29 \mathrm{bc}$ & $3.06 \mathrm{~d}$ \\
Nuclear Polyhedrosis virus(NPV) & $1.44 \mathrm{~cd}$ & $1.50 \mathrm{abc}$ & $1.99 \mathrm{abc}$ & $2.68 \mathrm{~cd}$ \\
Spinosad 45\% SC & $0.88 \mathrm{a}$ & $0.88 \mathrm{a}$ & $0.88 \mathrm{a}$ & $0.88 \mathrm{a}$ \\
Multineem & $1.35 \mathrm{bcd}$ & $1.95 \mathrm{bc}$ & $2.90 \mathrm{~cd}$ & $3.26 \mathrm{~d}$ \\
Furadan & $1.05 \mathrm{abc}$ & $1.33 \mathrm{ab}$ & $1.91 \mathrm{abc}$ & $3.38 \mathrm{~d}$ \\
Lara & $0.98 \mathrm{ab}$ & $0.98 \mathrm{a}$ & $1.30 \mathrm{ab}$ & $1.93 \mathrm{bc}$ \\
Magik & $0.87 \mathrm{a}$ & $0.87 \mathrm{a}$ & $1.28 \mathrm{ab}$ & $1.27 \mathrm{ab}$ \\
Control & $1.18 \mathrm{abcd}$ & $2.18 \mathrm{c}$ & $3.57 \mathrm{~d}$ & $4.99 \mathrm{e}$ \\
\hline P-value & 0.013 & 0.012 & 0.001 & $<.001$ \\
CV\% & 16.1 & 27.0 & 21.4 & 6.8 \\
SEM & 0.1266 & 0.2423 & 0.337 & 0.2733 \\
LSD & 0.3841 & 0.7348 & 1.024 & 0.829 \\
\hline
\end{tabular}

Means within a column with no letters in common are significantly different (protected LSD; $P<$ $0.05)$.

However, after the first spray, the damage percent on spinosad treated plot was not significantly different from the rest of the treatments except multineem and control. But after the second spray, spinosad is significantly similar to other treatments except for multineem, Metarhizimum and control plots. The damage percent on maize plant after the third spray was totally varied with the first two sprays. The damage on spinosad plot was significantly similar to the magik plots but varies to the rest of the treatments. Here, the damage percentage on the treated plots have been recorded as ups and downs over the times. The variation of damage percentage of M. separata in the field can be affected by various factors (Sharma, Sullivan, \& Bhatnagar, 2002) such as dispersal capacity of the pests, insect characteristics, insect host finding characteristics etc. The effectiveness of these materials also affected by their qualities and quantities. Cook et al., (2004) reported that spinosad was effective to control the beet armyworm compared to non-treated control. The damage percent of bio-pesticides (Metarhizium, NPV, multineem) sprayed plots were significantly higher than the chemical pesticides, means bio-pesticides are slow acting pesticides and their effect can be seen in the long run but not the knockdown effect like synthetic pesticides. However, furadan effects on maize plots have been found lower compared with the other chemical pesticides, because during granules application in the plant, could drop into the soil or could cause fewer chances of physical contact to the armyworm. 
b. Damage record by M. separata in 2016/2017

Table 2: Response of different pesticides on armyworm (Mythimna separata) damage in a maize field in 2016/17 in Chitwan, Nepal.

\begin{tabular}{lllll}
\hline Treatments & \multicolumn{4}{l}{ Damage \%) } \\
\cline { 2 - 5 } & Before spray & After 1st spray & After 2nd spray & After 3rd spray \\
\hline Metarrhizium anisopliae & $8.33 \mathrm{a}$ & $7.67 \mathrm{~b}$ & $8.33 \mathrm{bc}$ & $7.00 \mathrm{c}$ \\
Nuclear Polyhedrosis virus(NPV) & $4.00 \mathrm{a}$ & $8.33 \mathrm{~b}$ & $5.67 \mathrm{ab}$ & $5.67 \mathrm{abc}$ \\
Spinosad 45\% SC & $5.33 \mathrm{a}$ & $2.33 \mathrm{a}$ & $1.67 \mathrm{a}$ & $1.67 \mathrm{a}$ \\
Multineem & $4.67 \mathrm{a}$ & $4.67 \mathrm{ab}$ & $4.33 \mathrm{ab}$ & $4.33 \mathrm{abc}$ \\
Furadan & $5.33 \mathrm{a}$ & $7.67 \mathrm{~b}$ & $5.00 \mathrm{ab}$ & $4.33 \mathrm{abc}$ \\
Lara & $4.33 \mathrm{a}$ & $3.67 \mathrm{a}$ & $2.00 \mathrm{a}$ & $2.67 \mathrm{ab}$ \\
Magik & $3.67 \mathrm{a}$ & $5.00 \mathrm{ab}$ & $6.00 \mathrm{ab}$ & $6.00 \mathrm{bc}$ \\
Control & $5.00 \mathrm{a}$ & $13.33 \mathrm{c}$ & $12.00 \mathrm{c}$ & $13.33 \mathrm{~d}$ \\
\hline P-value & 0.568 & $<.001$ & 0.002 & $<.001$ \\
CV\% & 23.4 & 30.9 & 14.6 & 16.0 \\
SEM & 1.569 & 1.161 & 1.327 & 1.205 \\
LSD & 4.76 & 3.521 & 4.024 & 3.655 \\
\hline
\end{tabular}

Means within a column with no letters in common are significantly different (protected LSD; $P<0.05$ ).

The damage percent on maize plants over the treatments before spray were not significantly different $(\mathrm{P}<0.05)$. This information indicates, distribution of armyworm in maize field was almost similar and damage has just started in the field. Damage was also lowest in spinosad treated plot $(1.67 \%)$ as compared to the control plot (13.33\%) (Table2). Amendez et. al., (2002) and Williams et al., (2004) also reported that spinosad has the potentiality to control the many lepidopteran pests. The damage percentage on Metarhizium, NPV and Multineem treated plots also demonstrated the higher damage than others chemical-based pesticides. The effect of multineem and furadan were almost similar. Hence there is the potential of replacing the furadan, a chemical based pesticide by multineem, which is neem safe based bio-pesticide. Mainali et al. (2014) reported in his research reported cypermethrin was the effective insecticide for armyworm management.

\section{Yield loss}

The yield was highest in the spinosad treated plot $(9.8 \mathrm{t} / \mathrm{ha})$ followed by lara treated plot $(9.17$ t/ha) in 2015/16 (Table 3). Similarly, in 2016/17, spinosad treated plot gave the highest yield (9.123 $\mathrm{t} / \mathrm{ha}$ ) followed by lara treated plot $(8.697 \mathrm{t} / \mathrm{ha})$. The lowest yield was recorded in the control plot in both years (Table 3 ). The yield was significantly superior in spinosad treated plots compared with other treatments. However, the yield in Metarhizium, NPV, multineem, furadan, lara, magik treated plots were not significantly different, which indicates there is nothing different either using chemical pesticide or bio-pesticide. The same yield was found to almost all treatments except spinosad and control indicate that plants have the certain threshold level of pest damage which could not influence the yield. These varieties could be tolerant variety, those varieties can withstand the pest damage as a certain level of pest burden. From the point of view of pest management, if the yield has not influenced by biotic factors, we have to wait until and before the damage threshold level of the pest (Moreno-García, Condé, Bello-Bedoy, \& Lanz-Mendoza, 2014). Hence IPM has always given the priority for pest monitoring and regular field visit before adopting any pest management practices. 
Table 3: Yield response of different pesticides on armyworms (Mythimna separata) damage in a maize field in 2016/17 in Chitwan, Nepal.

\begin{tabular}{lll}
\hline & \multicolumn{2}{c}{ Yield(t/ha) } \\
\cline { 2 - 3 } Treatments & Yr. 2015/2016 & Yr. 2016/2017 \\
\hline Metarrhizium anisopliae & $6.85 \mathrm{~b}$ & $8.148 \mathrm{a}$ \\
Nuclear Polyhedrosis virus (NPV) & $6.98 \mathrm{~b}$ & $8.24 \mathrm{abcd}$ \\
Spinosad 45\% SC & $9.80 \mathrm{c}$ & $9.12 \mathrm{e}$ \\
Multineem & $6.86 \mathrm{~b}$ & $8.39 \mathrm{abcd}$ \\
Furadan & $6.96 \mathrm{~b}$ & $8.21 \mathrm{abc}$ \\
Lara & $9.17 \mathrm{c}$ & $8.69 \mathrm{cde}$ \\
Magik & $6.47 \mathrm{~b}$ & $8.21 \mathrm{ab}$ \\
Control & $4.55 \mathrm{a}$ & $7.18 \mathrm{f}$ \\
\hline P-value & $<.001$ & $<.001$ \\
CV\% & 9.9 & 1.9 \\
SEM & 0.579 & 0.1469 \\
LSD & 1.757 & 0.4455 \\
\hline
\end{tabular}

Means within a column with no letters in common are significantly different (protected LSD; $P<0.05$ ).

\section{CONCLUSION}

Maize is an important cereal crop grown in hilly parts of Nepal. Armyworm is a major crop limiting factors and reduced yield by $50 \%$ in almost maize growing districts. This is a polyphagous pest and damage has been recorded in most parts of Nepal in maize growing seasons. Though cultural and IPM is being used to some extent, however, pesticide use is still common for pest management in Nepal. The current use of pesticides in maize has influenced the health, biodiversity, and declining of pollinators in agro-ecosystem. The cost related to health deterioration, and biodiversity loss have been realized is far higher than the immediate cost of pesticide and yield increased by pesticide use. Hence, the selection of safe pesticide and encouraging farmers to use them is the main aim of this research. spinosad demonstrated the significantly more superior compound than any other bio-pesticide. This is also better than the orthodox pesticide to reduce the damage by $M$. separata and increase the yield. Spinosad has high efficacy, a broad insect pest spectrum, low mammalian toxicity, and a good environmental profile, a unique feature of the insecticide compared to others chemical compounds. Several types of research reported that this compound is environmentally friendly and have a low adverse effect on human health and the environment. Finally, the study has concluded that an environmental friendly and less hazardous pesticide spinosad $(0.25 \mathrm{ml} / \mathrm{lit}$ of water $)$ has been recommended for the effective control of this armyworm. The use of spinosad potentially reduce the pesticide hazardous level in maize and protect the health of farmers and finally promote the sustainable production in the Nepalese farming system. However, the large scale and multiyear studies in various geographical locations have been suggested before wider application of this technique.

\section{ACKNOWLEDGEMENT}

The authors would like to thank the National Maize Research Council (NARC) for providing the space for field experiment including other technical and logistic support. Finally, we would like to thank those who directly or indirectly supported to complete this study. 


\section{REFERENCES CITED}

Ali, A., Luttrell, R. G., \& Pitre, H. N. (1990). Feeding sites and distribution of fall armyworm (Lepidoptera: Noctuidae) Larvae on Cotton. Environmental Entomology, 19(4), 1060-1067. doi:10.1093/ee/19.4.1060.

Ali, A., Rashid, M. A., Huang, Q. Y., \& Lei, C.-L. (2016). Effect of UV-A radiation as an environmental stress on the development, longevity, and reproduction of the oriental armyworm, Mythimna separata (Lepidoptera: Noctuidae). Environmental Science and Pollution Research, 23(17), 17002-17007.

Amendez, W., Valle, J., Elbarra, J., Cisneros, J., Penagos, D. \& Williams, T. (2002). Spinosad and nucleopolyhedrovirus mixtures for control of Spodoptera frugiperda (Lepidoptera: Noctuidae) in maize. Biological control, 25(2): 195-206

Anonymous. (1976). Annual report 1978. Entomology Division. Nepal Agriculture Research Council, Khumaltar, Lalitpur, Nepal.

Brunner, J. F. (2014). Integrated pest management in tree fruit crops A2 - Alfen, Neal K. Van. In Encyclopedia of Agriculture and Food Systems (pp. 15-30). Oxford: Academic Press. Retrieved from http://www.sciencedirect.com/science/article/pii/B9780444525123001753. doi:http:// dx.doi.org/10.1016/B978-0-444-52512-3.00175-3.

Cloyd, R. A., \& Bethke, J.A. (2011). Impact of neonicotinoid insecticides on natural enemies in greenhouse and interiorscape environments. Pest Management Science, 67(1), 3-9. doi:10.1002/ps.2015.

Cook, D.R., Leonard, B.R. \& Gore, J. (2004). Field and laboratory performance of novel insecticides against armyworms (Lepidoptera: Noctuidae). Florida Entomologist, 87(4): 433-439.

GC, Y.D.\& Keller S. (2013). Crop pests of Nepal and their management. HELVETAS Swiss Intercooperation Nepal. $171 \mathrm{p}$.

Geiger, F., Bengtsson, J., Berendse, F., Weisser, W. W., Emmerson, M., Morales, M. B., \& Inchausti, P. (2010). Persistent negative effects of pesticides on biodiversity and biological control potential on European farmland. Basic and Applied Ecology, 11(2), 97-105. doi:http://dx.doi. org/10.1016/j.baae.2009.12.001.

Godfray, H. C. J., Blacquière, T., Field, L. M., Hails, R. S., Petrokofsky, G., Potts, S. G., \& McLean, A. R. (2014). A restatement of the natural science evidence base concerning neonicotinoid insecticides and insect pollinators. Proceedings of the Royal Society B: Biological Sciences, 281(1786). doi:10.1098/rspb.2014.0558.

Gyawali, B. K. 1974. Report of Entomology Division 2031-2032. Entomology Division, Department of Agriculture, Hariharbhawan, Nepal.

Hill, M. G. \& Atkins, A.W. ( 2012). Effects of defoliation by cosmopolitan armyworm, Mythimna separata (Walker) on Maize yield. New Zealand Journal of Agricultural Research, 25(2): 251254. https://doi.org/10.1080/00288233.1982.10420920.

Jiang, X., Zhang, L., Cheng, Y., \& Luo, L. (2014). Current status and trends in research on the oriental armyworm, Mythimna separata (Walker) in China. Chin. J. Appl. Entomol, 51, 881-889.

Joshi, S.L. (1978). Technical Report on Epidemic of Mythimna separata in Nuwakot and Rasuwa districts.

Juan, Z., Yuying, J., \& Jie, L. (2013). Analysis of the armyworm outbreak in 2012 and suggestions of monitoring and forecasting. Plant Protection. 5 (3): 125-126

Karuppuchamy, P., \& Venugopal, S. (2016). Chapter 21 - Integrated Pest Management. In Ecofriendly Pest Management for Food Security (pp. 651-684). San Diego: Academic Press. Retrieved from http://www.sciencedirect.com/science/article/pii/B978012803265700021X. doi:http:// dx.doi.org/10.1016/B978-0-12-803265-7.00021-X.

Mainali, R.P., Dangi, N., Aryal, S., Bhandari, G.S. \& Bajracharya, A.S.R. ( 2014). Management of armyworm outbreak in the rice field of Chitwan district. Asian Journal of Science and Technology, 5(12): 774-776 
McLaughlin, A., \& Mineau, P. (1995). The impact of agricultural practices on biodiversity. Agriculture, Ecosystems \& Environment, 55(3), 201-212. doi:http://dx.doi.org/10.1016/01678809(95)00609-V.

Moreno-García, M., Condé, R., Bello-Bedoy, R., \& Lanz-Mendoza, H. (2014). The damage threshold hypothesis and the immune strategies of insects. Infection, Genetics and Evolution, 24, 25-33.

Nagoshi, R. N., \& Meagher, R. L. (2004). Seasonal distribution of fall armyworm (Lepidoptera: Noctuidae) host strains in agricultural and turf grass habitats. Environmental Entomology, 33(4), 881-889. doi:10.1603/0046-225X-33.4.881

Neupane, F.P., Shrestha, S. M., Thapa, R. B. \& Adhikari, T.B. (1992). Crop protection (In the Nepali language). Institute of Agriculture and Animal Science, Rampur, Chitwan, Nepal.

Rana, P.N. \& Plumb, G.H. (1973). Report on the Ninth session of the plant protection committee of the South East Asia and Pacific Region, New Delhi, India.

Rana, P.N. (1975). The epidemic of Mythimna separata in Kavre and Sindhupalchowk districts.

Robinson, R. A., \& Sutherland, W. J. (2002). Post war changes in arable farming and biodiveristy in Grain Britain Journal of Applied Ecology, 39, 157-176.

Russell, E. P. (1989). Enemies hypothesis: a review of the effect of vegetational diversity on predatory insects and parasitoids. Environmental entomology, 18(4), 590-599.

Saville, D. J. (2015). Multiple comparison procedures - cutting the Gordian Knot. Agronomy Journal, 107(2), 730-735. doi:10.2134/agronj2012.0394

Sharma, H., \& Davies, J. (1983). The oriental armyworm, Mythimna separata (Wlk.). Distribution, biology and control: a literature review. The oriental armyworm, Mythimna separata (Wlk.). Distribution, biology and control: a literature review.(59).

Sharma, H. C., Sullivan, D. J., \& Bhatnagar, V. S. (2002). Population dynamics and natural mortality factors of the Oriental armyworm, Mythimna separata (Lepidoptera: Noctuidae), in South-Central India. Crop Protection, 21(9), 721-732. doi:https://doi.org/10.1016/S02612194(02)00029-7.

Shivakoti, G.P. \& KC, B. (1981). Screening of maize germination against maize borer Chilo partellus, Swinhoe, pp. 95-98. Ninth Summer Crops Workshop. National Maize Development Program, Rampur, Chitwan, Nepal.

Songa, J. M., Mugo, S., Mulaa, M., Taracha, C., Bergvinson, D., Hoisington, D. \& Groote, H. D. E. (2002). Towards the development of environmentally safe insect resistant maize varieties for food security in Kenya. Paper presented to the symposium on Perspectives on the evolving role of private/public collaborations in agricultural research. Organized by the Syngenta Foundation for Sustainable Agriculture, Washington, D.C., USA.

Tiwari, S., Dickinson, N., Saville, D. J., \& Wratten, S. D. (2018). Host plant selection by the Wheat Bug, Nysius huttoni (Hemiptera: Lygaeidae) on a range of potential trap plant species. Journal of Economic Entomology, 111(2), 586-594. doi:10.1093/jee/toy017.

Whitehorn, P. R., O’Connor, S., Wackers, F. L., \& Goulson, D. (2012). Neonicotinoid pesticide reduces bumble bee colony growth and queen production [10.1126/science.1215025]. Science, 336(6079), 351.

Williams, T., Cisneros, J., Penagos, D.I., Valle, J. \& Tamez-Guerra, P. (2004). Ultralow rates of Spinosad in Phagostimulant Granules provide control of Spodoptera frugipera (Lepidoptera: Noctuidae) in Maize. Journal of Economic Entomology, 97(2): 422-428.

Wood, G. R., \& Saville, D. J. 2013. A geometric examination of linear model assumptions. Aust. N. Z. J. Stat. 55: 285-303; doi: 10.1111/anzs. 12042. 